\title{
Gênero e política em Lima Barreto*
}

\author{
Magali Gouveia Engel ${ }^{* *}$
}

\begin{abstract}
Resumo
O artigo analisa as concepções de Lima Barreto em torno da problemática dominação/submissão/resistência nas relações entre homens e mulheres, através da análise de temas centrais em suas crônicas, contos e romances - perfis femininos, sexualidade, casamento, crimes passionais, feminismo.
\end{abstract}

Palavras-chave: Gênero, Lima Barreto, Política, Feminismo, Crimes Passionais.

\footnotetext{
* Recebido para publicação em agosto de 2007, aceito em agosto de 2008.

** Professora Doutora do Departamento de Ciências Humanas da Faculdade de Formação de Professores da UERJ. magaliengel@terra.com.br

cadernos pagu (32), janeiro-junho de 2009:365-388.
} 


\title{
Gênero e política em Lima Barreto
}

\author{
Gender and Politics in Lima Barreto
}

\begin{abstract}
This article analyses Lima Barreto's conceptions on domination, submission and resistance in the relationship between men and women. The research focuses on the female characters profiles, sexuality, marriages, crimes of passion, feminism - such as they are described in novels, tales and chronicles written by the author.
\end{abstract}

Key Words: Gender, Lima Barreto, Politics, Feminism, Crime of Passion. 
Partindo da convicção de que a questão de gênero representou um dos aspectos privilegiados na discussão do poder que permeia toda a obra de Afonso Henriques de Lima Barreto $(1881-1922)^{1}$, pretendo investigar os significados políticos das críticas ao domínio masculino e à submissão feminina formuladas pelo autor. ${ }^{2}$ Trata-se de um aspecto pouco explorado nas abundantes análises dos escritos limianos e, geralmente, revestido da ênfase na suposta postura machista do autor, apreendida em suas posições acerca do feminismo brasileiro do início do século $\mathrm{XX} .{ }^{3}$ Busca-se aqui enriquecer os enfoques que rompem com esta tendência, apresentando e discutindo as contribuições de Lima Barreto para o debate das problemáticas que envolvem, ainda hoje, a dimensão de poder nas relações de gênero.

A avaliação crítica das concepções do autor acerca da problemática dominação/submissão/resistência nas relações entre homens e mulheres encontra-se pautada na investigação de temas-chaves - feminismo, casamento, divórcio, crimes

1 Afonso Henriques de Lima Barreto era filho do tipógrafo João Henriques de Lima Barreto e da professora primária Amália Augusta Barreto, ambos mestiços. Completados os primeiros estudos no Liceu de Niterói, Lima Barreto foi para o Colégio Pedro II. Em 1897, entrou para a Escola Politécnica de Engenharia, na qual, em 1902, iniciou a sua colaboração no periódico dos estudantes, A Lanterna. Após o enlouquecimento do pai e a quinta reprovação no curso de Mecânica, Lima Barreto abandonou a Escola de Engenharia, ingressando no funcionalismo público. Um dos mais importantes escritores brasileiros, pretendeu fazer de sua literatura um instrumento de transformação social, denunciando as desigualdades raciais e de classe que caracterizavam a sociedade em que viveu, bem como as arbitrariedades dos primeiros governos republicanos.

2 As reflexões aqui apresentadas baseiam-se nos resultados das pesquisas "Paixão e crime: um estudo das relações de gênero no Rio de Janeiro (18901930)" e "Trabalho, relações de gêneros e questão racial: memórias da cidade através das crônicas (Rio de Janeiro, 1870-1930)", já concluídas. Ambos os projetos contaram com o apoio do CNPq e da FAPERJ. Na pesquisa sobre Lima Barreto atuaram como bolsistas de Iniciação Científica Tania Mittelman e Daniel Morais Angelim.

3 Exceções importantes e que inspiram a análise aqui desenvolvida são os estudos de Maria Zilda Ferreira Cury (1981) e de Eliane Vasconcellos (1992). 
Gênero e política em Lima Barreto

passionais, relações homens-mulheres, relações entre mulheres nos escritos selecionados em função do rico potencial que oferecem para a abordagem proposta no presente estudo. Desse modo, foram privilegiados os romances Triste fim de Policarpo Quaresma 4 e Clara dos Anjos 5 , os contos "O filho de Gabriela", "Cló", "Lívia" e "Adélia"6; e as crônicas sobre o feminismo e os uxoricídios citadas ao longo do texto.

Como qualquer outra fonte, as crônicas, os contos, os romances $e$ as poesias são produzidos historicamente $e$, portanto, devem ser inseridos "no movimento da sociedade", cabendo ao historiador "investigar as suas redes de interlocução social" $e$ elucidar o modo como elaboram ou expressam "a sua relação com a realidade social", sempre presente, mesmo quando não explicitada, conforme assinalaram Sidney Chalhoub e Leonardo Pereira na "Apresentação" de História Contada (Chalhoub e Pereira, 1998:8). Obras de ficção, certamente, mas nem por isso isentas de uma determinada lógica social, cuja identificação e interpretação são pressupostos indissociáveis da análise histórica.

Tecidas no cotidiano da vida e situadas nas interseções entre a ficção e a realidade, as crônicas expressam, como observou Margarida de Souza Neves "indícios reveladores do tempo vivido" (Neves, 1995). Lima Barreto foi um dos mais importantes e brilhantes cronistas brasileiros, escrevendo sobre variados temas sempre sob uma perspectiva crítica e perspicaz característica de sua obra. Entre as questões do seu tempo por ele abordadas, o movimento feminista brasileiro de inícios do século

${ }^{4}$ Escrito entre janeiro e março de 1911, o romance foi publicado sob a forma de folhetim na edição da tarde do Jornal do Commercio. O livro só sairia em fevereiro de 1916 em edição custeada pelo próprio autor.

5 A primeira versão do romance começou a ser escrita em 1904 e a segunda em dezembro de 1921. Em maio de 1922, o primeiro capítulo desta segunda versão, concluída em janeiro, foi publicado na revista $O$ Mundo Literário. O livro completo foi publicado postumamente em 1948 pela editora Mérito (RJ).

6 Todos incluídos pelo autor no livro História e sonhos, publicado em 1920 pela Livraria Editora de Gianlorenzo Schettino (RJ). 
passado e duas de suas principais lideranças assumem um lugar de destaque nos escritos que publicou em vários periódicos. ${ }^{7}$ Afirmando-se explicitamente anti-feminista nas crônicas "Carta aberta" (1921) e "O feminismo em ação" (1922), questionou a legitimidade das reivindicações sustentadas pelo movimento feminista coevo - qualificado pelo autor como "feminismo burocrata" -, centradas em torno do direito de voto e do acesso a cargos públicos.

Para o escritor, a admissão de mulheres como funcionárias públicas constituía um "equívoco político", pois a lei não permitia que elas exercessem funções públicas - exceto nos telégrafos, nos correios e no magistério:

Nos Telégrafos e Correios, as moças têm acesso, porque os respectivos regulamentos - autorizados pelo Congresso permitem. Nas outras repartições, não; é um abuso. Mulher não é, no nosso direito, cidadão (Lima Barreto, 2004:526, I). ${ }^{8}$

Lima introduz, portanto, a questão essencial da exclusão das mulheres da cidadania - embora não se disponha a aprofundá-la - que parece escapar à pauta de lutas do feminismo. Vale destacar

7 As crônicas do autor foram reunidas por Beatriz Resende e Rachel Valença em Toda crônica (Lima Barreto, 2004). Segundo a classificação temática das autoras são as seguintes que se referem ao feminismo: A amanuensa, A.B.C., 5/10/19018; O nosso caboclismo, Careta, 11/10/1919; Novidades, Careta, 22/11/1919; O Dr. Frontin e o feminismo, Careta, 14/02/1920; Legião da Mulher Brasileira, A.B.C., 27/03/1920; As mulheres na Academia, Careta, 19/02/1921; O nosso feminismo, Careta, 16/04/1921; Voto feminino, Careta, 9/07/1921; Uma nota, Careta, 27/08/1921; Carta aberta, Careta, 24/09/1921; A poliantéia das burocratas, Rio-Jornal, 26 e 27/09/1921; Feminismo e voto feminino, Careta, 7/01/1922; O feminismo invasor..., A.B.C., 21/01/1922; O feminismo em ação, Careta, 18/04/1922; Uma atuação de Dona Berta, Careta, 6/05/1922; Feminismo internacional, Careta, 3/06/1922; O nosso feminismo, A.B.C., 12/08/1922.

8 Trata-se da crônica intitulada "Quereis encontrar marido? - Aprendei!...", publicada originalmente no periódico Hoje, em 26 de junho de 1919. Nela o autor tece comentários bastante sarcásticos sobre o livro de Dona Diana D'Alteno, Quereis encontrar marido? - Aprendei!... 
Gênero e política em Lima Barreto

ainda que o escritor não faz restrições ao acesso das mulheres aos empregos públicos legalmente permitido. Em "Carta aberta" (1921) chega mesmo a explicitar:

Nunca neguei capacidade alguma na mulher. O meu antifeminismo não parte do postulado da incapacidade da mulher, para isso ou para aquilo; é baseado em outros motivos, mais de ordem social do que mesmo de natureza fisiológica ou psicológica (Lima Barreto, 2004:415, II).

Por outro lado, não é possível negar que o cronista constrói ou veicula, em vários momentos, imagens bastante desqualificadas das mulheres, revelando visões muito contraditórias. Nesta mesma crônica uma senhora que tendo se envolvido numa especulação ilegal, segundo o autor, saiu-se muito bem ao lidar com "cousas de polícia e de justiça", expressando uma nova faceta da feminilidade, fruto das conquistas das reivindicações feministas. O exemplo da tal senhora que enfrentou as autoridades com uma "energia nervosa", capaz de muita "matreirice" em vez de assumir a velha atitude chorosa mostrou que "o sexo feminino deu um passo além; sabe de pronto emaranhar juízes e delegados" (Lima Barreto, 2004:415, II), driblando as leis.

Em "A amanuensa" (1918), Lima Barreto afirma que os lugares públicos são "naturalmente" masculinos e sua "invasão" pelas mulheres prejudicaria "a regularidade da reprodução da nossa raça" e que estas, ao desenvolverem serviços mais adequados aos homens, acabam por "prejudicar a perpetuidade da espécie humana no planeta" (Lima Barreto, 2004:389, I). ${ }^{9} \mathrm{O}$

9 O autor cita a afirmação de Spencer em seu Introdução à Ciência Social de que depois que as mulheres na Europa assumiram "serviços exercidos normalmente pelos homens... as dimensões exigidas para os recrutas eram diminuídas", ou seja, elas passaram a gerar filhos menos fortes e saudáveis. Lima Barreto menciona também Krafft-Ebing que diz ser o casamento a profissão da mulher. Ambas as idéias encontram-se na crônica já citada "Quereis encontrar marido? - aprendei!...". 
homem, associado a progresso é mais resistente do que a mulher, identificada à conservação e, por isso, menos apta a enfrentar o "sedentarismo de uma mesa de secretaria". As moças possuíam uma inteligência reprodutora e, portanto, mais propícia para o "estudo de línguas muito do gosto das repartições catitas, como o Itamarati", porém não eram nunca capazes de "iniciativa, de combinação de imagens, dados concretos e abstratos que definam a verdadeira inteligência" (Lima Barreto, 2004:389, I).

Embora o discurso do escritor expresse no seu sentido explícito a crença na existência de uma natureza feminina aparentemente universal, marcada por características negativas, é possível, muitas vezes, apreender em suas dimensões mais submersas e subliminares o reconhecimento da pluralidade das experiências femininas. No exemplo que acabamos de ver as moças de "inteligência reprodutora" parecem ter um rosto social bem definido: eram aquelas que falavam "francês ou alemão".

$\mathrm{Na}$ crônica "As mulheres na Academia" (1921), Lima Barreto faz uma crítica à concepção de literatura predominante nos meios acadêmicos, uma literatura que "nada tinha a ver com a vida, com os seus choques inevitáveis, com as dores dos outros, com os problemas do nosso destino e da sociedade":

...porque as mulheres não compreendem nada disto; porque elas não têm uma visão larga e profunda da Humanidade; porque elas nunca viram a dor dos humildes nem se interessaram por ela; por isso é que elas são grandes escritoras (Lima Barreto, 2004:317, II).

Cabe indagarmos, quem seriam essas mulheres? Eram as moças que sabiam recitar nas salas e salões de Botafogo ao Méier, que sabiam se "vestir muito bem com pouco dinheiro" - o que era fundamental num contexto em que "a literatura é um negócio de contramestre de casa de confecções... e modas". Eram as "melindrosas" que desfilavam na Avenida e que nada sabiam "a respeito da dor de uma pobre rapariga criada de servir". Eram, 
Gênero e política em Lima Barreto

enfim, as moças que estudaram no Colégio Sion onde aprenderam a falar razoavelmente o francês e que desprezavam todos os homens e mulheres que não faziam parte de sua roda, gente que para elas não tinham alma, "como certo concílio afirmou no tocante às mulheres" (Lima Barreto, 2004:316, II). É possível, portanto, fazer uma leitura da crônica que confira uma fisionomia social bem definida à categoria mulheres empregada num sentido, à primeira vista, generalizante, no trecho acima citado.

Em "A poliantéia das burocratas" (1921), o cronista atribui à natureza feminina qualidades específicas para o exercício dos cargos públicos de amanuenses, escriturários e oficiais, funções meramente burocráticas. ${ }^{10}$ Nesse sentido, observa ironicamente que as mulheres possuíam letras praticamente idênticas, o que para ele revelava-se uma qualidade perfeitamente adequada ao padrão das repartições públicas, onde não havia lugar para as diferenças e a criatividade, o que inclusive teria levado à adoção nesses espaços da "impessoal máquina de escrever". A ausência de individualidade e de temperamento, bem como o comportamento submisso, tornavam as mulheres portadoras de uma vocação natural para o exercício de "um simples cargo público" (Lima Barreto, 2004:418, II). Além disso, Lima Barreto, concordando com o chefe de seção do Ministério da Agricultura, Marcos Martins, afirma que muitas moças conseguiam ter sucesso nos concursos e exames por causa do "prestígio das saias". Mas tal sucesso não decorria somente do protecionismo por serem mulheres, mas também da aptidão natural destas para "a retenção e para a repetição":

...não filtram os conhecimentos através do seu temperamento, não os incorporam à sua inteligência, ficam sempre como estáticos a elas, não os renovam em si. Daí, a sua pouca capacidade de invenção e criação; mas daí

${ }^{10}$ Vale lembrar que Lima Barreto exerceu durante muito tempo amanuense da Secretaria da Guerra, o que lhe despertou profunda angústia e insatisfação. 
também os seus sucessos nos exames e concursos. Tudo está na ponta a língua..." (Lima Barreto, 2004:422, II).

No caso desse texto, o discurso de Lima parece mesmo construir e veicular uma desqualificação das mulheres em geral. Mesmo assim, vale observar que o olhar do escritor não deixa de ser informado pela preocupação com a diversidade. Reconhece que surpreendentemente havia poucas "descendentes de Filaminta" nesse "feminismo paletó de alpaca" ou "rond-decuir": "Todas as representantes dele são moças simples, que só têm o desejo de ter um ordenado razoável para se manter $e$ auxiliar os parentes. Nada mais justo e respeitável..." (Lima Barreto, 2004:421, II). Aqui o cronista está se referindo às "moças e meninas recentemente nomeadas funcionárias públicas, depois do feminismo burocrático, instituído pelo Senhor Nilo Pessanha" (Lima Barreto, 2004:418, II), entrevistadas pelo jornal A Noite. Desse modo, pode-se perceber uma divisão entre as "representantes do feminismo" (as moças simples) e sua liderança - que na crônica em questão é Berta Lutz (1894-1976) ${ }^{12}$-, completamente distante da realidade da maioria das mulheres brasileiras trabalhadoras, ao lutar pelo "direito da mulher ao trabalho próprio":

...minha senhora, então a mulher só veio a trabalhar porque forçou as portas das repartições públicas? Ela sempre trabalhou, minha senhora, aqui e em toda a parte, desde que o mundo é mundo; e até, nas civilizações primitivas, ela trabalhava mais do que o homem. Dou o meu testemunho pessoal. Desde menino... que [a] vejo trabalhar em casa, fora de casa, em oficinas, ateliers de

\footnotetext{
${ }^{11}$ Personagem da peça Les Femmes Savantes de Molière (1622-1673).

12 Uma das pioneiras da luta pelo voto feminino no Brasil, a cientista Berta Lutz, foi uma das primeiras mulheres a ingressar no serviço público ao ser aprovada no concurso para o Museu Nacional no Rio de Janeiro em 1919. Neste mesmo ano criou a Liga para a Emancipação Intelectual da Mulher e em 19 de agosto de 1922 fundou a Federação Brasileira pelo Progresso Feminino (cf. Besse, 1999).
} 
Gênero e política em Lima Barreto

costura e até na roça, plantando, colhendo, guiando bois ao arado, etc." (Lima Barreto, 2004:420, II).

Em seguida lembra a visita à Fábrica de Tecidos Rink com o amigo e ex-colega Noronha Santos, onde viu "muitas mulheres junto aos teares e outros maquinismos". Entre elas, chamou-lhe a atenção uma

negra velha que, sentada no chão, tinha diante de si um monte de lã, limpa, alva, recentemente lavada quimicamente, e o seu cabelo... era já tão branco $e$ encaracolado que desafiava a alvura da lã que estava diante dela (Lima Barreto, 2004:420, II).

Refere-se também às moças com aventais pardos e cabelos empoeirados que embrulhavam livros na Livraria do Alves e pergunta à Berta Lutz, "essas moças não trabalhavam?".

Para o autor, o "feminismo caricato" não estaria preocupado com a "dignificação", nem com a "elevação" da mulher, mas sim em reivindicar os "lugares de amanuenses com cujos créditos possa comprar vestidos e adereços, aliviando nessa parte os orçamentos dos pais, dos maridos e dos irmãos" (Lima Barreto, 2004:350, II). ${ }^{13}$ Aqui, o acesso ao emprego público não significaria a ruptura da sujeição econômica dessas mulheres que, para sobreviverem, continuariam a depender do trabalho masculino. Longe de representar as mulheres trabalhadoras anteriormente mencionadas, o feminismo brasileiro dos primeiros tempos republicanos era um movimento de mulheres brancas $e$ burguesas. Na crônica "O feminismo invasor", por exemplo, o escritor satiriza a atuação de Berta Lutz através da personagem "Dona Adalberta Luz", fundadora da "Liga pela Manumissão da Mulher Branca" (Lima Barreto, 2004:491, II) que aparece em muitas outras de suas crônicas. No conjunto das crônicas analisadas é possível apreender com clareza as bases étnico-sociais e políticas

13 Trata-se da crônica intitulada "O nosso feminismo". 
que sustentavam o movimento feminista alvo dos ataques de Lima Barreto:

Não me move nenhum ódio às mulheres, mesmo porque não tenho fome de carne branca; mas o que quero é que essa coisa de emancipação da mulher se faça claramente, após um debate livre, e não clandestinamente... (Lima Barreto, 2004:545, II).

No que se refere, pois, à defesa do acesso das mulheres aos cargos públicos, um dos itens centrais da agenda do feminismo brasileiro das primeiras décadas do século XX, a postura assumida por Lima Barreto revela-se perfeitamente coerente com a sua posição crítica diante das arbitrariedades das práticas políticas republicanas. O que está em questão não é o direito da mulher ao trabalho, e até mesmo aos empregos públicos, mas sim as vias de acesso das mesmas ao exercício destes cargos então vigentes, absolutamente ilegítimas, porque acima das leis. Como ele próprio afirma, o que está em jogo é "a maneira irregular e ilegal que tem presidido o provimento desses cargos por moças e senhoras" (Lima Barreto, 2004:418, II). Um dos episódios que suscita uma firme contestação do escritor foi a decisão de um ministro de inscrever uma moça, à última hora, em um concurso para a repartição que chefiava:

Resolveu isso, sem prorrogar, porém, a inscrição para que outras, nas mesmas condições o fizessem também.

[Diante do fato, comenta]

...esse feminismo rond-de-cuir nasceu torto e aleijado por diversas razões e há duas principais. Primeira: um ministro não tem competência para decidir sobre semelhantes assuntos, isto é, equiparação de direitos do sexo feminino ao masculino; segunda: se ele resolveu, no caso vertente, essa equiparação, à última hora, devia, para mostrar isenção de ânimo, prorrogar a inscrição, a fim de que se apresentassem outras candidatas, tanto mais que, na data $e$ 
Gênero e política em Lima Barreto

durante a publicação do respectivo edital, não se admitia tal equiparação (Lima Barreto, 2004:419, II).

$\mathrm{Na}$ passagem, ficam evidenciados os significados políticos das críticas de Lima Barreto: de um lado, o desrespeito à lei como característica do exercício do poder pelas autoridades republicanas $e$, de outro, as práticas clientelísticas que garantiam o acesso aos empregos públicos e outros tipos de benesses. Nesse sentido, vale destacar que o problema não era a aspiração de muitas moças pobres a tais empregos com o fim de auxiliarem no sustento de suas famílias (ao contrário das provenientes dos segmentos médios), mas sim a forma arbitrária e autoritária através da qual algumas poucas (protegidas) o conseguiam. "Não sou inimigo das mulheres, mas quero que a lei seja respeitada, para sentir que ela me garante" (Lima Barreto, 2004:526, I).

Lima ataca, portanto, não apenas os móveis, mas também as estratégias do "feminismo burocrata", não poupando suas lideranças - entre as quais se destacam as figuras de Leolinda Daltro (1859-1935) ${ }^{14}$ e a da já mencionada Berta Lutz. Ambas são acusadas de estarem profundamente comprometidas com os esquemas corruptos, marcados pela ideologia do favor $e$ pelas práticas clientelísticas da política institucional da Primeira República. De acordo com o autor, a segunda teria pedido ao funcionário designado pelo ministro a emitir um parecer sobre a concessão do direito às mulheres de serem admitidas em concursos públicos que fosse favorável ao programa da Liga pela Emancipação da Mulher.

\footnotetext{
${ }^{14}$ Uma das fundadoras do Partido Republicano Feminino em 1910, que defendia a abertura de cargos públicos às mulheres. É sempre referida como Deolinda Daltro nas crônicas de Lima Barreto e, segundo Eliane Vasconcellos, seria retratada como D. Florinda Seixas no romance Numa e a ninfa, publicado sob a forma de folhetins no jornal carioca A Noite em 1915 e em 1917 sob a forma de livro (Cf. Vasconcellos, 1992: 258).
} 
Esta senhora... devia saber que não é decente ninguém insinuar a um funcionário, seja por que meio for, que os seus pareceres sejam dados em tal ou qual sentido. Em certas ocasiões chega a ser até crime... (Lima Barreto, 2004:406, II).

Dona Daltro foi ainda acusada por Lima de liderar uma campanha no Senado a favor da aprovação do projeto que concedia às mulheres o direito de voto, à frente de "um bando de senhoras, senhoritas e meninas, carregadas de flores" que despejavam "as pétalas sobre a cabeça do respeitável e imenso senador Lopes Gonçalves" (Lima Barreto, 2004:375, II). Muito irônico o autor afirma que apesar de não ser simpático ao projeto achava-o útil, já que conferia "às casas do parlamento feições floridas e gentis de sala de baile ou platéia de teatro", esvaziando, assim, de conteúdo político as ações das feministas. Diz ainda que segundo um jornal da cidade do Rio, as "senhoras andavam aos abraços com os senadores", concluindo em tom sarcástico e desqualificador: "Uma lei que nasce de abraços, só pode ser favorável aos destinos da Pátria" (Lima Barreto, 2004:376, II).

Um aspecto importante para compreendermos os significados políticos que levaram Lima Barreto a se opor veementemente ao voto feminino refere-se à situação de profunda dependência à qual as mulheres encontravam-se submetidas na sociedade brasileira nas primeiras décadas republicanas. Equiparadas, no próprio âmbito legal, aos loucos, aos menores e aos interditos estariam "sempre debaixo de tutela e proteção de quem ela carece irremediavelmente" (Lima Barreto, 2004:544, II), ou seja, de figuras masculinas. As especificidades que determinam os lugares ocupados pelas mulheres nessa sociedade hierarquizada e clientelística determinam, pois, no entender do autor, o agravamento da ausência de autonomia indispensável para o livre exercício do direito de voto e para o uso correto $e$ legítimo da autoridade pressuposta no desempenho de certas funções públicas. 
Gênero e política em Lima Barreto

A defesa do acesso das mulheres aos empregos públicos e do voto feminino fazia do movimento feminista "um partido de 'cavação', como qualquer outro masculino" (Lima Barreto, 2004:472, I), contribuindo para a preservação do sistema clientelístico e da ideologia do favor no âmbito da política institucional, tão criticados pelo escritor. Ao não questionar as instituições e práticas políticas vigentes, autoritárias e excludentes, terminava por reforçá-las, centrando suas reivindicações na participação do esquema que sustentava a "República dos Bruzundangas". ${ }^{15}$ Além disso, a postura de Lima Barreto diante do voto não seria estranha às concepções anarquistas que condenavam todo o tipo de participação na política institucionalizada irremediavelmente impregnada de conteúdo burguês.

Especificamente no campo das questões relativas à situação das mulheres, as feministas compactuavam, segundo a visão do escritor, com os valores e práticas machistas que faziam das mulheres escravas na sociedade brasileira. Ao invés de se baterem por causas que colocassem em xeque efetivamente a dominação masculina - assentada na própria maneira através da qual a sociedade encontrava-se estruturada - perdiam tempo com bandeiras conservadoras. Torna-se, portanto, essencial recuperarmos o conteúdo das críticas e denúncias feitas pelo escritor diante das práticas machistas características da sociedade brasileira, através, por exemplo, de sua campanha a favor do divórcio. Em sua obra, Lima Barreto revela a preocupação em denunciar o aviltamento das mulheres pela instituição do casamento, em torno do qual viam-se obrigadas a estruturarem todas as expectativas de suas vidas. Assim, por exemplo, no caso da personagem Ismênia (Lima Barreto, 1986), o abandono do noivo $e$, conseqüentemente, o risco de ficar solteira colocava-a

${ }^{15}$ Livro reunindo sátiras de Lima Barreto sobre a república brasileira, publicado pela primeira vez por Jacinto Ribeiro dos Santos em 1923, após a morte do escritor. 
numa situação que a afastava do destino que, de acordo com os padrões dominantes seria o único considerado "natural" $e$ "normal" para todas as mulheres, levando-a ao enlouquecimento $e$ à morte. Vale ressaltar que, inspirado nas idéias maximalistas, Lima Barreto propõe quatro medidas básicas que viabilizariam uma reforma radical da sociedade brasileira, entre as quais figurava justamente o "estabelecimento do divórcio completo". ${ }^{16}$

Estimulado pela projeção que os crimes passionais passaram a adquirir na imprensa carioca a partir da segunda década do século $\mathrm{XIX}^{17}$, Lima Barreto cobra das feministas uma crítica contundente à instituição do casamento:

Contra um ignóbil e iníquo estado de espírito dessa ordem, que tende a se perpetuar entre nós, aviltando a mulher, rebaixando-a ao estado social da barbárie medieval, de quase escrava; degradando-a à condição de cousa, de animal doméstico, de propriedade nas mãos dos maridos...; não lhe respeitando a consciência e liberdade de amar a quem lhe parecer melhor, quando e onde quiser; contra tão desgraçada situação da nossa mulher casada, edificada com estupidez burguesa e a superstição religiosa, não se insurgem as borra-bostas feministas que há por aí (Lima Barreto, 2004:472, I).

Para o escritor, o divórcio seria, portanto, uma reivindicação muito mais legítima e conseqüente politicamente, na medida em

${ }^{16}$ Veja-se as crônicas "No ajuste de contas..." (Lima Barreto, 2004:336-343, I), crônica publicada originalmente no periódico A.B.C. em 11 de maio de 1918 e "Sobre o maximalismo" (Lima Barreto, 2004:459-465, I), publicada originalmente na Revista Contemporânea, $1^{\circ}$ de março de 1919.

${ }^{17}$ Segundo Susan Besse, embora não seja possível verificar se efetivamente houve um aumento significativo dos crimes passionais na cidade do Rio de Janeiro nas primeiras décadas republicanas, conforme afirmam vários registros da época, observa-se de fato um redimensionamento das repercussões em torno desses crimes, sobretudo a partir dos anos 1910, assumiram um novo perfil, tornando-se objeto de forte preocupação social e passando "...a ser vivenciados como algo particularmente ameaçador" (Besse, 1989:183). 
Gênero e política em Lima Barreto

que recusava radicalmente a reificação das mulheres pelo domínio masculino, eliminando as condições que asseguravam aos homens o direito de vida e de morte sobre suas companheiras. Através de algumas de suas crônicas ${ }^{18}$, Lima Barreto foi uma das primeiras vozes que se opuseram à absolvição ou à condenação branda dos "matadores de mulheres" e um crítico contumaz das concepções que sustentaram a transformação de Evaristo de Morais num dos mais famosos defensores dos chamados criminosos passionais. ${ }^{19}$

Outro aspecto importante na abordagem das condições sob as quais viviam as mulheres na sociedade brasileira é o que se refere à articulação estabelecida por Lima Barreto entre dominação, relações de gênero, questão racial e condição social. Mais uma vez, o olhar do escritor revela uma profunda sensibilidade, apreendendo as mulheres sempre no plural e nunca isoladas. Desse modo, suas reflexões permitem, por exemplo, uma avaliação das relações de poder entre mulheres ricas e pobres, negras ou mulatas e brancas, patroas e empregadas, etc. Vejamos alguns exemplos.

No conto "O filho de Gabriela", a dona-de-casa e a criada enfrentam-se numa clara explicitação das tensões sociais que marcam a relação de dominação. A reconciliação é possível

${ }^{18}$ As seguintes crônicas tratam do tema: "Não as matem", Correio da Noite, 21/01/1915; "Lavar a honra, matando?", Lanterna, 28/01/1918; "Os matadores de mulheres", Lanterna, 18/03/1918; "Os uxoricidas e a sociedade brasileira", Revista Contemporânea, 8?/03/1919; "Mais uma vez", A.B.C.?, 1920?.

${ }^{19}$ As questões relacionadas à chamada criminalidade passional têm suscitado importantes reflexões, norteadas por diferentes enfoques, entre os quais se destacam, por exemplo, o estudo pioneiro de Mariza Corrêa (1981) e o já citado artigo de Susan Besse (1989). A referida temática assume uma dimensão privilegiada ainda nos trabalhos de Boris Fausto (1984); de Sidney Chalhoub (1986) e de Rachel Soihet (1989). Dediquei-me a uma análise mais aprofundada sobre os conflitos, envolvendo relações afetivas e/ou sexuais entre homens e mulheres ocorridos na cidade do Rio de Janeiro entre fins do século XIX e inícios do XX nos seguintes textos: "Paixão, crime e relações de gênero (Rio de Janeiro, 1890-1930)" (Engel, 2000); "Cultura popular, crimes passionais e relações de gêneros - Rio de Janeiro, 1890-1930" (Engel, 2001) e "Relações de gêneros, violência e modernidade nas crônicas cariocas" (Engel, 2006). 
através do estabelecimento de uma identidade entre ambas, cujas bases, contudo encontram-se estruturadas sobre as partilhas decorrentes não de uma condição feminina, mas sim da situação comum enquanto seres humanos:

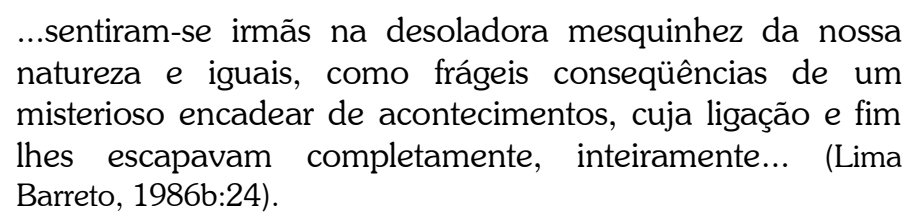

A reconciliação não anularia, entretanto, as profundas diferenças que separavam as duas mulheres pertencentes a universos sócio-culturais distintos e conflitantes. A condição dominada e dependente de Gabriela permanece intocada tanto na decisão de sair do emprego, quanto mais tarde na de retornar à casa de sua ex-patroa Laura.

Também no romance Clara dos Anjos é possível observarmos que a ótica do autor encontra-se sempre permeada pela percepção das profundas discriminações de classe e étnicas que tornam impossível pensarmos numa condição feminina no singular. Nesse sentido, a narrativa desautoriza qualquer possibilidade, por exemplo, de estabelecermos uma identidade entre as moças seduzidas por Cassi (moço proveniente de uma família suburbana de prestígio) - Inês, uma "crioulinha" que havia trabalhado como copeira em sua casa; Luísa, empregada do doutor Camacho; Santinha que ajudava a mãe a costurar para fora; Bernarda que trabalhava no "Joie de Vivre"; Nair, filha de uma viúva muito pobre; e a própria Clara, mulata e filha de uma família humilde - e suas irmãs, Catarina e Irene que, formadas uma pela Escola Nacional de Música e a outra pela Escola Normal, sonhavam em se casar com "doutores, bem empregados ou ricos" (Lima Barreto, 1983:20).

Longe de negadas, ou mesmo secundarizadas, na denúncia das desigualdades características da sociedade brasileira, as 
Gênero e política em Lima Barreto

relações entre os gêneros adquirem na obra limiana tonalidades específicas, revelando a complexidade e a multiplicidade das estratégias e das práticas de dominação masculina. Os sofrimentos e frustrações de Laura, por exemplo, que a conduzem a uma aproximação com Gabriela e seu filho Horácio, eram decorrentes do casamento com o conselheiro: “...casada, sem filhos, não encontrando no casamento nada que sonhara, nem mesmo o marido, sentiu o vazio da existência, a inanidade dos seus sonhos..." (Lima Barreto, 1986b:28). Como vimos, bastante recorrente na obra de Lima Barreto, a crítica à instituição do casamento denuncia e condena a imposição social de um único sentido à existência feminina, ser esposa e mãe. Se na caracterização das condições de submissão de Laura as referências diretas ao seu marido são indispensáveis, de forma bem distinta, o domínio masculino faz-se presente na experiência de Gabriela através do silêncio total em relação à presença de um companheiro ou do próprio pai de seu filho. Como parte significativa das mulheres pertencentes às classes trabalhadoras, Gabriela é a provedora de si própria e do filho, sendo a figura masculina uma presença passageira em sua vida.

A reificação das mulheres como um dos desdobramentos inevitáveis do domínio machista, denunciada na defesa do divórcio, é outro aspecto importante das concepções críticas de Lima Barreto em relação às vivências femininas. Este é um dos temas tratados no conto "Lívia" (Lima Barreto, 1986b), no qual a protagonista alimenta a ilusão de libertar-se da "tirania do cunhado" e das "impertinências do pai" através do casamento, sem perceber que a condição de "corça domesticada", e portanto de submissão, marcava não apenas o seu relacionamento com os homens da família, mas também com seus namorados - nos quais buscava desesperadamente o futuro marido, sem sucesso.

$\mathrm{O}$ projeto de ascensão social através de relacionamentos sexuais é visto por Lima Barreto como uma outra forma de reificação da mulher. A personagem Clódia - ou Cló -, por exemplo, é comparada a uma "escrava desprezada". Filha de 
Maximiliano, um humilde lente, empenhava-se em seduzir o doutor André, casado, "bacharel vulgar e deputado obscuro" - de acordo com a avaliação de seu pai -, recebendo agrados como um bracelete falso. O perfil de mulheres como Cló são traçados por Lima Barreto de forma cruel:

...a moça, pondo tudo o que havia de sedução na sua voz, nos seus olhos pequenos e castanhos, cantou a "Canção da preta mina":

Pimenta de cheiro, jiló, quimbombô;

Eu vendo barato, mi compra ioiô!

Ao acabar, era com prazer especial, ...que ela, sacudindo as ancas e pondo as mãos dobradas pelas costas na cintura, curvava-se para o doutor André e dizia vagamente:

Mi compra ioiô!

E repetia com mais volúpia, ainda uma vez:

Mi compra ioiô! (Lima Barreto, 1986b:126).

Contudo, o comportamento da personagem não é visto como um atributo da natureza feminina - que, tão ao gosto lombrosiano ${ }^{20}$, então em voga, manifestava-se em condições (biológicas ou do meio) favoráveis -, mas como decorrência do aviltamento moral produzido por instituições sociais pautadas no preconceito, na exploração e na extrema desigualdade, heranças recentes da sociedade escravista.

Não se trata também de condenar um comportamento sexual feminino mais livre, o que seria revelar um moralismo estranho à proximidade de Lima Barreto com certas concepções anarquistas que inspiraram o seu discurso em defesa do divórcio. A trajetória de Adélia, protagonista de outro conto do autor (Lima Barreto, 1986b), parece confirmar isso. De origens muito humildes, ela se casa com um trabalhador que, apesar de pobre, pôde proporcionar-lhe durante os dois primeiros anos "o ócio" que

${ }^{20} \mathrm{O}$ famoso médico e criminologista Cesare Lombroso (1835-1909) foi um dos fundadores do direito positivo italiano e defendia a teoria do criminoso nato. 
Gênero e política em Lima Barreto

"afinou-a, melhorou-a". Depois que o marido adoeceu, Adélia prostituiu-se para assegurar a sobrevivência de ambos. Apesar de ter conseguido enriquecer morreu nova, com trinta e poucos anos sem nunca ter-se apagado de seu rosto o "olhar duro e perverso" que adquirira quando foi vítima da assuada dos meninos porque casara-se a pé. Esposa indiferente, prostituta sem vontade, Adélia parece à deriva em sua própria existência à qual jamais conseguiria dar um sentido, pois nada apagara a absoluta ausência de lugar oriunda das origens sociais da "menina de estalagem".

As relações entre Ricardo Coração dos Outros e Olga, personagens do romance Triste fim de Policarpo Quaresma, representam uma outra dimensão importante, através da qual é possivel tentar penetrar o universo das relações de gênero em Lima Barreto. Olga, uma das muitas personagens femininas fortes que marcam a obra limiana, expressa a possibilidade de "superação de uma consciência ingênua da realidade" (Cury, 1981:75). Ao longo da trama vai, paulatinamente, tornando-se mais madura e, em decorrência, mais crítica e segura, ao mesmo tempo em que os traços do seu caráter tornam-se mais sólidos. $\mathrm{O}$ tocador de violão de origens populares, cuja fama se espalhava por toda a cidade, possui como traços característicos de sua personalidade simples a honestidade e a integridade. Como bem observou Maria Zilda Cury, Ricardo e Olga, ao se tornarem cúmplices na solidariedade incondicional a Quaresma - quando este, vítima das arbitrariedades do governo de Floriano Peixoto (1891-1894), acaba condenado à morte - expressam a certeza da possibilidade da transformação $e$ a esperança de um futuro mais justo e igualitário. A relação entre esses personagens pode ser lida como uma espécie de metáfora do equilíbrio que asseguraria a tolerância diante das diferenças e, assim, o fim da hierarquização de classe, de raça e de gênero. É significativo que o encontro, a cumplicidade, a aliança entre um homem e uma mulher tenham servido para expressar o próprio projeto social e político de Lima Barreto. 
Convicto de fazer da literatura missão (Sevcenko, 1983), conferindo-lhe um papel efetivo de transformação social, Lima Barreto foi um agente profundamente atuante na sociedade em que viveu. Dilacerado por permanentes conflitos entre suas origens sociais (pobre e mulato) e a condição de letrado sofreu $e$ expressou as contradições daqueles que não possuem um lugar, atormentados pela constante sensação de não pertencimento ou de inadaptação, traduzida por tantos de seus personagens (Policarpo Quaresma, Adélia, Vicente ${ }^{21}$, entre muitos outros). Apesar de suas ambigüidades e contradições, Lima Barreto não perde nunca a coerência $e$ a honestidade em relação aos princípios que defende, nem mesmo quando, com todo o seu antifeminismo, enfrenta algumas das questões fundamentais que permeavam (e ainda permeiam) as relações homens-mulheres na sociedade brasileira.

Muito distante dos discursos que ridicularizavam $e$ vulgarizavam o feminismo através de palavras e de imagens, amplamente veiculados pela imprensa do período, bem como das posições conservadoras que levantavam a bandeira do antifeminismo como uma das estratégias de combate à democracia liberal, Lima Barreto opôs-se não apenas ao feminismo institucionalizado da Federação Brasileira pelo Progresso Feminino de Berta Lutz, mas também às posições feministas católicas da Revista Feminina. Longe das concepções defendidas por homens - como o renomado psiquiatra Antonio Austregésilo Lima - que valorizavam a emancipação feminina, exclusivamente, enquanto uma forma de garantir "a evolução da raça e a prosperidade da nação" (Besse, 1999:214), o escritor aproximava-se de posturas profundamente questionadoras dos padrões que norteavam as relações de gênero na sociedade brasileira das primeiras décadas do século $\mathrm{XX}$, tais como as

${ }^{21}$ Vicente é o protagonista do romance baseado nas vivências das duas internações no Hospício Nacional de Alienados (em 1914 e em 1919) que o escritor deixou inacabado, cujo primeiro capítulo foi publicado na Revista Souza Cruz em 1921 (Lima Barreto, 1988). 
Gênero e política em Lima Barreto

assumidas por mulheres como Maria Lacerda de Moura e Patrícia Galvão, a famosa Pagu.

Com a primeira partilhou uma visão crítica do movimento feminista ancorado nos setores médios urbanos que, inspirada em certas vertentes do ideário anarquista, suscitava a questão colocada pela autora do livro "A mulher é uma degenerada?":

De que vale a igualdade de direitos jurídicos e políticos para meia dúzia de privilegiadas, tiradas da própria casta dominante, se a maioria feminina continua vegetando na miséria da escravidão milenar? (Moura, 1932:12). ${ }^{22}$

Com a inquietante Pagu - apesar de ter morrido antes que ela se tornasse conhecida - certamente teria compartilhado a crítica radical à instituição burguesa do casamento, bem como o ataque às feministas que

ao invés de viverem como "parasitas", dependendo da exploração de suas empregadas domésticas para terem sua liberdade [deveriam lutar primeiro] para superar a pobreza e a exploração de classe (apud Besse, 1999:202). ${ }^{23}$

Espero ter conseguido, através destas breves reflexões sobre a riqueza das possibilidades de interpretação das questões relativas a gênero nos registros limianos, indicar a pluralidade das concepções e posicionamentos sobre o tema nos debates que marcaram os primeiros movimentos feministas brasileiros. Nesse sentido, gostaria de ter contribuído aqui para incentivar investigações que aprofundem a análise desta dimensão essencial

${ }^{22}$ Moura foi uma das fundadoras, juntamente com Lutz, da Liga pela Emancipação Intelectual Feminina em 1919, mas com a mudança para São Paulo aproximou-se de um grupo anarquista e rompeu com o movimento feminista (Besse, 1999).

${ }^{23}$ Em 1931, Pagu entrou para o Partido Comunista Brasileiro, mas pouco tempo depois incompatibilizou-se com a linha puritana que o caracterizava na época. 
da obra de um dos maiores e mais importantes escritores brasileiros, estabelecendo e aprofundando os diálogos, permeados por partilhas e tensões, que ele estabeleceu com diversas vozes que lhe foram contemporâneas.

\section{Referências bibliográficas:}

BESSE, Susan K. Modernizando a desigualdade: reestruturação da ideologia de gênero no Brasil. São Paulo, Edusp, 1999.

. Crimes passionais: a campanha contra os assassinatos de mulheres no Brasil: 1910-1940. Revista Brasileira de História (18), São Paulo, ago./set. 1989, pp.181-197.

CHAlHOUB, Sidney. Trabalho, lar e botequim. O cotidiano dos trabalhadores no Rio de Janeiro da Belle Époque. São Paulo, Brasiliense, 1986.

. e PEREIRA, Leonardo A. de M. Apresentação. In: A história contada: capítulos de história social da literatura no Brasil. Rio de Janeiro, Nova Fronteira, 1998.

CORRÊA, Mariza. Os crimes da paixão. São Paulo, Brasiliense, 1981.

CURY, Maria Zilda Ferreira. Um mulato no Reino de Jambom (as classes sociais na obra de Lima Barreto). São Paulo, Cortez, 1981.

ENGEL, Magali Gouveia. Relações de gêneros, violência e modernidade nas crônicas cariocas. In: SILVA, Gilvan V. da; NADER, Maria Beatriz; FRANDO, Sebastião P. (orgs.) História, mulher e poder. Vitória, EDUFES, 2006, pp.220-234.

. Cultura popular, crimes passionais e relações de gêneros Rio de Janeiro, 1890-1930. Gênero (2), Niterói, NUTEG, 2001, pp.107-122.

Paixão, crime e relações de gênero (Rio de Janeiro, 18901930). Topoí(1), Rio de Janeiro, PPGH-UFRJ, 2000, pp.153-177.

FAUSTO, Boris. Crime e cotidiano. A criminalidade em São Paulo (18801924), São Paulo, Brasiliense, 1984. 
Gênero e política em Lima Barreto

NEves, Margarida de S. História da crônica. Crônica da história. In: RESEndE, Beatriz. (org.) Cronistas do Rio. Rio de Janeiro, José Olympio/ CCBB, 1995, pp.15-31.

SEVCENKO, Nicolau. Literatura como missão. São Paulo, Brasiliense, 1983.

SOIHET, Rachel. Mulheres pobres e violência no Brasil urbano. In: DEL PRIORE, Mary. (org.) História das mulheres no Brasil. São Paulo, Contexto, 1997, pp.362-400.

. Condição feminina e formas de violência. Mulheres pobres e ordem urbana. 1890-1920. Rio de Janeiro, Forense Universitária, 1989.

VASCONCELLOS, Eliane. Lima Barreto: misógino ou feminista? Uma leitura de suas crônicas. In: CANDIDO, Antonio e outros. A crônica: o gênero, sua fixação e suas transformações no Brasil. CampinasSP/Rio de Janeiro, Ed. Unicamp/FCRB, 1992, pp.255-269.

\section{Fontes:}

LIMA BARRETO. Toda crônica. Rio de Janeiro, Agir, 2004, 2 vols.

. O cemitério dos vivos. Rio de Janeiro, Secr. Mun. de Cultura, 1988.

. Triste fim de Policarpo Quaresma. $2^{a}$ ed. São Paulo, Ática, 1986a.

O filho de Gabriela; Lívia; Cló; Adélia. In: LIMA BARRETO. Os melhores contos. $2^{\text {a }}$ ed. Rio de Janeiro, Global, $1986 \mathrm{~b}$.

. Clara dos Anjos. 10ª ed. São Paulo, Brasiliense, 1983.

MouRA, Maria Lacerda de. A mulher é uma degenerada? Rio de Janeiro, Civilização Brasileira, 1932. 